\title{
Revenue-Generating Schemes for International Unions
}

\author{
Andrii O. Boiar \\ Vadym Hetman Kyiv National Economic University, Kyiv,Ukraine
}

\begin{abstract}
This paper investigates possible options for generating revenue in international unions. The empirical evidence is found for three types of revenue-generating schemes: contributions, direct taxes, and the combination of two. Discussion of peculiarities, advantages and shortcomings of each scheme led to the conclusion that financial needs, interstate heterogeneity, objectives and success of integration are the key factors determining the choice of a revenue-generating scheme. There is no clear pattern in the distribution of the schemes among different international unions. However, mixed scheme becomes more preferable to ensure sustainable financing international unions. Also, direct tax scheme would be the infant stage of a tax union that had no precedent in the modern history of economic integration.
\end{abstract}

JEL Classifications: F55, E62, G28

Key Words: Revenue, International Union, Budget, Contribution, Tax

\footnotetext{
* Corresponding Author: Andriy O. Boyar; European Integration Department of Vadym Hetman Kyiv National Economic University (KNEU), 54/1, Peremogy prospect, Kyiv 03680, Ukraine; Tel/Fax: +380 443716145, E-mail: Aboyar@kneu.edu.ua, boyar_andriy@yahoo.com.

Acknowledgements: The Author is grateful to colleagues from the European Integration Department and, particularly, to Viktor Chuzhykov for valuable comments and suggestions. Thank you also to the officials of international unions who replied and helped with data and information.
} 


\section{Introduction}

Since the Second World War, international integration has boosted immensely in terms of both geographic and sectoral coverage. There is hardly a country that is not involved in this process today. These arguments make every type of international union, ranging from free trade areas to monetary and economic unions, intriguing subject. ${ }^{1}$ This is especially true when it comes the issue of financing mechanisms of the unions that remains little explored.

There is also a practical need in filling for theoretical vacuum which exists around the issues of revenue-generating in international organizations, since financial stability is one of the main factors for successful operation of any international organization.

The issues are quite interesting even from the purely cognitive point of view. There may exist peculiar features, in the supranational budgeting process, being different from national or subnational budgeting.

Budgetary issues of the European Union, are provided with the theory of fiscal federalism in Alesina et al. (2005), Buti and Nava (2003), Tabellini (2003), behavioural budgeting theory Hoole et al. (1976), national costs and benefits theory in Carruba (1997), Hix (1999) the efficiency of centralized fiscal spending in international unions is estimated in Simon and Valasek (2012).

Still the lack of exploration remains an issue of theoretical foundations for revenuegenerating in international unions. Even in the classical economic integration literature, it is omitted (Viner 1950, Meade 1955, Balassa 1961, Tinbergen 1965). However, addressing these questions could help the unions to find ways to increase their efficiency and sustainability.

Thus, this article pursues objectives to synthesize theoretical models of revenuegenerating in international unions to discuss factors determining selection of a particular scheme. The study will generate more impulse for further developments in this area.

The investigation is primarily based on empirical data retrieved from official documentation of 23 international unions. ${ }^{2}$ An overview of revenue sides in budgets

\footnotetext{
${ }^{1}$ International union in this study is regarded as a voluntary association of sovereign states that decide to centralize or coordinate certain policies and confer corresponding powers to central supranational bodies.

${ }^{2}$ Namely the European Union (EU), the Association of Southeast Asian Nations (ASEAN), the Gulf Cooperation Council (GCC), the East African Community (EAC), the Central American Integration System (SICA), the Economic and Monetary Community of Central Africa (CEMAC), the Southern Common Market (MERCOSUR), the Southern African Customs Union (SACU), the West African Economic and Monetary Union (WAEMU), the European Free Trade Association (EFTA), the Eurasian Economic
} 
is provided in Section II. Based on it, three theoretical schemes of financing an international union are outlined examined and further developed in Section III. Section IV discusses factors determining the choice of a scheme and then concludes.

\section{Overview of Budgetary Revenues}

\section{A. Eurasia}

Among all international unions, the European Union (EU) is the most complicated in terms of mechanisms in its revenue-generation system. Article 311 of the Treaty on the Functioning of the European Union (former article 269 of the Treaty establishing the European Community) states that the budget shall be financed wholly from own resources (EU 2008). This implies that own resources and other revenues comprise two groups of budgetary revenues for the EU.

According to current legislation, the EU own resources are constituted (EU 2007) as:

(1) Common Customs Tariff duties and other duties established or to be established by the institutions of the Communities

(2) the application of a uniform rate ${ }^{3}$ valid for all member-states to the harmonized Value Added Tax (VAT) assessment bases according to Community rules. The assessment base is taken into account for this purpose shall not exceed $50 \%$ of GNI for each member-state;

(3) the application of a uniform rate ${ }^{4}$ to the sum of all the member-states' Gross National Incomes (GNIs).

\footnotetext{
Community (EurAsEC), the Customs Union of Belarus, Kazakhstan, and Russia (CUBKR), the Southern African Development Community (SADC), the Caribbean Community (CARICOM), the Union of South American Nations (from Sp. UNASUR), the Andean Community (CAN), the Organization of Eastern Caribbean States (OECS), the Common Market for Eastern and Southern Africa (COMESA), the Economic Community of West African States (ECOWAS), the Central European Free Trade Agreement (CEFTA), the Greater Arab Free Trade Area (GAFTA), the South Asian Free Trade Area (SAFTA), the North American Free Trade Agreement (NAFTA).

${ }^{3}$ For 2011 , this uniform rate was established at $0.3 \%$.

${ }^{4}$ For 2011 , this rate was calculated to be $0.7538236 \%$.
} 
The first source of own resources is usually referred to as Traditional Own Resources (TOR) since they have been established since the creation of Customs Union in 1968. The second and the third are called VAT own resource and GNI own resource, correspondingly. GNI resource is also called residual resource because it finances part of budgetary revenues that is not covered by all other revenues. For many years, the latter makes up the majority of financial resources of the EU. ${ }^{5}$

Besides these three sources of revenue, a bunch of other related mechanisms are considered. They include common rules to calculate harmonized VAT bases and GNIs of the member-states, mechanisms limiting own resources that can be charged to member-states.

The rest of the EU budgetary revenues comprise surplus available from the preceding financial year, correction and adjustment contributions and refunds in connection with EU agreements and programs, interests on late payments and fines and revenue from borrowing and lending operations.

Since its early times, the EU underwent significant transformations for its revenuegenerating rules and procedures. During 1958 1983, direct contributions from members' national budgets were an important revenue source for the EU budget. The customs duties were introduced as a revenue source in 1968; VAT resource was established since 1978; and GDP resource became effective in 1988 (Pietras 2008, p. 16). During late 1970 s and in 1980s some other elements were introduced in the revenue-generating system of the EU, in particular, corrections in the form of reductions in contributions in favour of some member-states.

Most of international unions in Eurasia are financed through direct member-states' contributions from their national budgets, according to politically agreed and legally binding rules. For instance, in the Central European Free trade Agreement (CEFTA) the contribution quotas are approved by the CEFTA Joint Committee every three years, taking into account economic capacity of member-states. According to the Decision No. $7 / 2007$, Croatia and Serbia each covered $25 \%$ of the common budget costs, Bosnia and Herzegovina 12.5\%, Macedonia 11\%, Albania 8\%, Montenegro and the United Nations Interim Administration Mission in Kosovo 6.5\% each and Moldova 5.5\% (CEFTA 2007). Significant part of the CEFTA budget is made up by the EU donation.

\footnotetext{
5 In 2011, share of GNI resource in total own resources was $75.6 \%$. At the same time TOR and VAT resource constituted $13.4 \%$ and $11.0 \%$, correspondingly.
} 
Contributions of the European Free Trade Association (EFTA) member-states to the common budget in the financial year 2013 were as follows: Iceland covered $3.07 \%$ of the budgetary needs, Lichtenstein $0.93 \%$, Norway $55.85 \%$, and Switzerland $40.15 \%$ (EFTA 2013). These shares are determined proportionally to member-states' shares in total EFTA GDP. Macroeconomic indicators are averaged for the last three years to even out short period fluctuations. These shares are then weighted by a political factor related to the fact that Switzerland is non-participant in the European Economic Area (EEA) Agreement. Since significant part of the EFTA Secretariat expenses goes to the EEA related activities, this country is granted a rebate as for its contribution which is redistributed among other members. ${ }^{6}$

Other (non-contribution) EFTA budgetary revenues are made up by surplus from previous financial year, write-offs, interest income, realised and unrealised exchange rate differences and bank charges (EFTA 2012). If a member-state is in arrears with the payment of its contributions, interest on arrears of 10 per cent per annum shall be charged, payable by the member-state together with the next contribution to the association (EFTA 2009).

As for the budgetary revenues in the Eurasian Economic Community (EurAsEC) and in the Customs Union of Belarus, Kazakhstan, and Russia (CUBKR) also seem interesting. In these unions, administrative budgets are financed by member-states' contributions that are calculated as shares in the common budget in proportion to the number of votes each member has in permanent authorizing bodies of the unions (Commission for the CUBKR and Integration Committee for the The Eurasian Economic Community EurAsEC). ${ }^{7}$ As for recent years in the EurAsEC, these shares were established at 15\% each for Belarus, Kazakhstan and Uzbekistan, 40\% for Russia and 7.5\% each for Kyrgyzstan and Tadzhikistan. ${ }^{8}$ In the CUBKR they were $21.5 \%$ for each of Belarus and Kazakhstan and 57\% for Russian Federation. ${ }^{9}$ Since 2011 in CUBKR, the contributions were made proportional to each member's share in total amount of import duties. Today, Belarus is responsible for $4.7 \%$ of the CUBKR budgetary resources, Kazakhstan's share is $7.33 \%$ and the Russian Federation's share

\footnotetext{
${ }^{6}$ Information provided on the 25 of January 2013 by Tore Grønningsæter - EFTA Senior Information and Communication Officer.

${ }^{7}$ It must be noted that this approach is not new. It is used by IMF for many years.

${ }^{8}$ See article 15 of the Treaty Establishing Eurasian Economic Community (with corrections and amendments of 25 January 2006 and of 6 October 2007) (EurAsEC 2000).

${ }^{9}$ See article 7 of the Treaty about Commission of the Customs Union of 6 October 2007 (CUBKR 2007).
} 
makes $87.97 \%$. $^{10}$

Contributions to finance common non-administrative programs and activities are subjected to separate decisions by the Interstate Council which is the supreme body of the EurAsEC. These decisions must be based on the degree of participation from the parties.

All expenses of the Gulf Cooperation Council (GCC) are equally distributed among its member-states. ${ }^{12}$ The same revenue-generating principle is applied in the Association of Southeast Asian Nations (ASEAN). ${ }^{13}$

The Greater Arab Free Trade Area (GAFTA) is a project of the Social and Economic Council of the Arab League. Its administrative and financial provisions are carried by member states of the Arab League.

In the South Asian Association for Regional Cooperation (SAARC), different bodies and programs are budgeted according to different schemes that are subject of separate political decisions of the SAARC member-states. However, there rarely is a single rule and often special arrangements are applied to certain members. Administrative expenditures of the SAARC Secretariat, for example, are financed according to agreed scale of national contributions but the initial cost of construction of the main building of the Secretariat had to be met by the host government of Nepal. Similar principles are applied to financing of other SAARC bodies and their regional subdivisions. In case of transnational activities, the local expenses including hospitality, are borne by the host government within agreed limits while the cost of air travel is met by the sending government (International Labour Office 2013).

Program expenditures are financed via national contributions and other resources. For instance, the SAARC Development Fund (SDF) ${ }^{14}$ is made up with callable and paid-up member-states' contributions and other revenues from borrowings, loan repayments, commission on guarantees, income derived from loans made.

\footnotetext{
${ }^{10}$ See article 5 of the Treaty about establishment and application in the Customs Union of the order of distribution of import duties of 20 May 2010 (http://tsouz.ru/MGS/mgs21-05-10/Pages/Sogl_o_mexanizme_zachisl_poshlin.aspx).

${ }^{11}$ See article 15 of the Treaty Establishing Eurasian Economic Community.

${ }^{12}$ See article 18 of the Charter of the Cooperation Council for the Arab States of the Gulf (GCC 1981).

${ }^{13}$ See article 30 of the Association of Southeast Asian Nations Charter (ASEAN 2007).

${ }^{14}$ Its initial authorised capital is SDR 1 billion (approx. 1.5 billion US dollars). See article 3 of the Charter of the SAARC Development Fund (SDF) (SAARC 2008).
} 


\section{B. America}

In the Southern Common Market (MERCOSUR), budgets of permanent authorities are financed by equal contributions from all member-states. ${ }^{15}$ At the same time, financial resources for special funds and programs are generated through different contributions of the member-states that take part in corresponding programs. ${ }^{16}$

Contributions from national budgets are the main revenue source for budgets of the Andean Community (CAN) institutions like General Secretariat, and Court of Justice. ${ }^{17}$

Initially, budgetary revenues in the Central American Integration System (SICA) ${ }^{18}$ comprised by national contributions that is calculated in proportion to dues that member-states pay in accordance to their UN financial obligations. ${ }^{19}$ Later the rules of contributions changed and after the Tegucigalpa Protocol administrative came into force, budgets of the SICA are financed equally by all the member-states. ${ }^{20}$

Activities of the structures of the North American Free Trade Agreement (NAFTA) are financed by the member-states. First of all, it concerns regional sections of the NAFTA Secretariat (NAFTA 2013).

Revenues of the Organization of Eastern Caribbean States (OECS) budget are divided into two categories: core and donor revenues. Core revenues are made up primarily by contributions that member-states pay from their national budgets according to the rule: all six independent states pay $16 \%$ each of necessary resources and the rest is equally distributed among three non-independent countries (OECS 2008). First category also includes revenues received from activities of the OECS bodies. ${ }^{21}$ Donor revenues comprise aid from the third parties of states and international organizations. The latter revenue source plays very important role for the OECS. ${ }^{22}$

Financial provisions of the OECS primary legislation do not allow unbalanced

\footnotetext{
${ }^{15}$ For example, budget of the MERCOSUR Administrative Secretariat in financial year 2013 was established at 4.208 million US dollars; each member-state paying 841.5 thousand US dollars (MERCOSUR 2012).

${ }^{16}$ For instance, budget of the MERCOSUR Structural Convergence Fund is annually increased per 100 million US dollars, out of which Brazil pays 70\%, Argentina 27\%, Uruguay 2\%, Paraguay 1\%. Additionally the Fund is financed by unutilized costs, surpluses from preceding years, voluntary additional contributions of member-states etc. Its budget in 2011 totalled to 682.131 million US dollars (MERCOSUR 2010).

${ }^{17}$ See article 22 of the Andean Subregional Integration Agreement (CAN 1969).

${ }^{18}$ Initially the name of the organization was Organization of Central American States (ODECA).

${ }^{19}$ See article 3 of the Charter of Organization of Central American States (SICA 1962).

${ }^{20}$ See article 32 of Tegucigalpa Protocol of the Charter of the Organization of the Central American States (SICA 1991).

${ }^{21}$ In particular, the Pharmaceutical Procurement Services (PPS) and the Eastern Caribbean Liaison Services Office (ECLS).

${ }^{22}$ For instance, in the budget of the OECS Annual Work Programme for financial year 2012 2013 totalling to 81.6 million EC dollars (approx. 30 million US dollars), donor aid accounted for 77\% (OECS 2012).
} 


\section{budget. $^{23}$}

The financing of the ordinary budget for the General Secretariat of the Union of South American Nations (UNASUR) is based on contribution of the member-states to be determined by the Council of Ministers of Foreign Affairs, taking into account economic capacity of the member-states, shared responsibility, and principle of equity. ${ }^{24}$

Member-states' budgetary contributions in the Caribbean Community (CARICOM) is based on the capacity to pay (CARICOM 2006). GDP is used as an indicator for capacity to pay.

\section{Africa}

The regular budgets of the Economic Community of West African States (ECOWAS) and its institutions are funded from a community levy and other sources determined by the ECOWAS Council. The community levy is a percentage share of the total value of import duty derivable from goods imported into the Community from the third countries. The percentage rate is regularly corrected by the Council, taking into account the financial needs of the ECOWAS. Special budgets can be made available when necessary. $^{25}$

Part of the revenue received by member-states from common customs tariff and indirect taxes constitutes own resources of the West African Economic and Monetary Union (WAEMU). This budgetary resource is called Community Solidarity Levy. Rates of transfers are decided annually, taking into account budgetary expenditures and revenues. The WAEMU budget must be in balance. In due course of time, it is planned to establish the Union VAT that will replace part of national indirect taxes. ${ }^{26}$ Loans, grants and external financial aids can also constitute the WAEMU budgetary revenues if they do not contradict the goals of the organization. ${ }^{27}$

Principle of financial solidarity applied in the WAEMU is a unique feature of this organization's budgetary system. It means that when discussing budgetary issues,

\footnotetext{
${ }^{23}$ See article 17 of the Treaty of Basseterre Establishing the Organisation of Eastern Caribbean States Economic Union (OECS 2010).

${ }^{24}$ See article 16 of the South American Union of Nations Constitutive Treaty (UNASUR 2008).

${ }^{25}$ See articles 70-73 of the Revised Treaty of the Economic Community of West African States (ECOWAS 1993).

${ }^{26}$ See articles 47, 54 and 55 of the Treaty of West African Economic and Monetary Union (WAEMU 1994).

${ }^{27}$ In the 2013, WAEMU budget, totalling to CFA francs 106.608 billion (approx. 162.5 million euro), Community Solidarity Levy accounted for $68.4 \%$; the rest fell on other resources.
} 
member-states are not allowed to refer to equivalence between their budgetary contribution and benefits that they receive from membership in the union as an argument. $^{28}$

Similar scheme, except for solidarity principle, underlies revenue-generating in the Economic and Monetary Community of Central Africa (CEMAC). Its own resources are made up by the Community Integration Levy, ${ }^{29}$ which is a part of the Community Common Customs Tariff. Together with other possible revenues (income from activities of the CEMAC institutions; levy on each member-state's share of distributed profits of the Bank of Central African States (BEAC); external aid) the Levy finances two types of budgets: administrative budgets of the CEMAC institutions and the budget of the Community Development Fund.

According to article 50 of the Revised Treaty of Economic and Monetary Community of Central Africa administrative budgets of the CEMAC institutions and bodies are financed on the basis of equality. ${ }^{30}$ The Community Integration Levy is the main source of these financial resources. In case when the Levy does not provide with necessary amount, residual must be paid as direct transfer from national budget.

The budget of the Community Development Fund comprises leftovers from the Levy and $20 \%$ of the BEAC distributed profits (CEMAC 2011b).

Collection and transfer of the Community Integration Levy is an exclusive competence of the member-states' customs bodies (CEMAC 2000). Members that are in arrears with their payments can be deprived of the voting rights in all bodies of the CEMAC and ceased to enjoy the benefits of the common economic area provided by the CEMAC legislation. Organization's budgets must be in balance.

Common Revenue Pool makes the main source of budgetary revenues in the Southern African Customs Union (SACU). It comprises all customs, excise and additional duties collected in the Common Customs Area during each financial year. However, only small part of these duties is directed to finance activities of the SACU itself, called operational budget. $^{32}$ The rest of the money is distributed among the member-states

\footnotetext{
${ }^{28}$ See article 49 of the Treaty of West African Economic and Monetary Union (WAEMU 1994).

${ }^{29}$ Since 2002 its rate is $1 \%$ of value of all imported to CEMAC goods (CEMAC 2000).

${ }^{30}$ For instance, total budget of the CEMAC institutions and agencies in financial year 2012 was equal to CFA francs 25.304 billion (approx. 38.6 million euro). This amount was financed by each of 6 CEMAC member-states in equal shares (CFA francs 4.217 billion) (CEMAC 2011a).

${ }^{31}$ See articles 49 and 52 of the Revised Treaty of the Economic and Monetary Community of Central Africa (CEMAC 2008).

${ }^{32}$ In 2011 2012 financial year (1 April 31 March) operational budget of the organization was 43.181 million rands (approx. 4.3 million euros), $94 \%$ of which came from the Common Revenue Pool and the rest were made up by other revenues (SACU 2013).
} 
according to rather complicated formula (Kirk 2003) after the operational budget has been approved.

The SACU member-states have to carry out appropriate payments to the Common Revenue Pool during the second quarter of each financial year. The amount are estimated based on forecasted values of the duties. ${ }^{33}$

Administrative and program expenditures in the Common Market for Eastern and Southern Africa (COMESA) are financed in different ways. Administrative budgets are for permanent bodies of the organization, the Secretariat and Court of the COMESA. They are financed through differentiated member-states' contributions that are decided by the COMESA Council, taking into account the estimated expenditures and resources available from other sources of grants, donations, income of the COMESA institutions. Contributions which are calculated according to the formula must be similar for both bodies and be reconsidered regularly. ${ }^{34}$

Program expenditures are directly related to the formation of the common market. They have to be covered by special duty called the Common Market Levy. ${ }^{35}$

Annual budgets of the East African Community (EAC) are made up of equal contributions from member-states' national budgets. They can be complemented by regional and international grants, donations, technical assistance, revenue generated by the Community itself and its bodies. ${ }^{36}$

Member-states' budgetary contributions in the Southern African Development Community (SADC) are on the basis of their GDP levels. The growth rate of annual national contributions cannot exceed annual GDP's average growth rate in the Community (SADC 2009). It should be noted that SADC, similar to other international unions of developing countries, shows significant dependence on external revenue sources.

\footnotetext{
${ }^{33}$ See articles 32 and 35 of the 2002 Southern African Customs Union Agreement (SACU 2002).

${ }^{34}$ See articles 42 and 166 of the Agreement Establishing the Common Market for Eastern and Southern Africa (COMESA 1993).

${ }^{35}$ See article 168 of the Agreement Establishing the COMESA (COMESA 1993). I wasn't able to find more detailed information on mechanism of generation of this revenue.

${ }^{36}$ See articles $132-133$ of the East African Community Treaty (EAC 1999).

${ }^{37}$ Of 39.36 million US dollars budget in financial year 2007 2008 41.1\% were made up by grants from international organizations and developed countries (such as African Development Bank, European Union, World Bank, Forum for Agricultural Research in Africa (FARA), Food and Agriculture Organization (FAO), United Nations Organization, Belgium, France, Switzerland, the United Kingdom, and others) (SADC 2009).
} 


\section{Financing Schemes}

Section II provided empirical evidence that there are three schemes for revenuegenerating in international unions: (i) member-states pay that is determined by direct contributions from national budgets (contributions scheme); (ii) direct supranational taxes are introduced (direct taxes scheme) and (iii) mixed scheme that combines elements of the two. One should note that in most cases, the simplest unions do not create supranational budgets. Their activities are financed from national budgets of the parties that undertake these activities or host the events.

All current international unions with constituted budgets more or less fit in this classification. Most of them are financed via contributions and only some generate their revenues through taxes or the combination of both (Figure 1).

Figure 1. Revenue-generating Schemes of International Unions

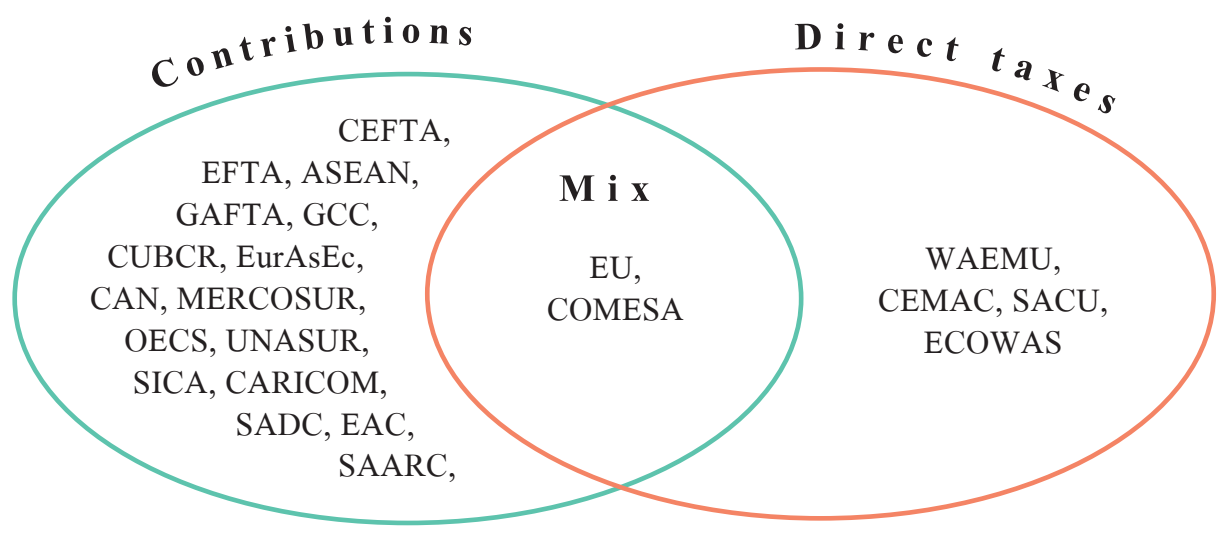

The direct taxes scheme and the mixed scheme are commonly practiced in either rather advanced (EU, WAUMU, CEMAC) or rather ambitious in terms of pursued goals (COMESA, SACU, ECOWAS) unions. It can be explained by the popular understanding that application of direct supranational taxes for revenue-generating purposes in international unions ensures higher financial sustainability of the unions themselves. However, as it is argued in Boiar (2013) that revenue source is not the 
major factor of financial stabilization in international unions. The facts that problems of late, erroneous or failed payments are proper to organizations financed by different schemes confirm this hypothesis.

\section{A. Contributions}

Under contributions scheme, an international union's budget is financed according to formula:

$$
Y=a+\sum_{i=1}^{n} y_{i} x_{i}
$$

where $Y$ represents planned level of expenditures and, correspondingly, revenues; $a$ represents other (non-contribution) budgetary revenues; $n$ represents number of member-states in a union; $x_{i}$ represent percentage share of state $i$ in total budgetary contributions (that is $\left.\sum_{i=1}^{n} x_{i}=100 \%\right) ; y_{i} x_{i}-$ size of budgetary contribution of state $i$ calculated according to expression $y_{i}=\frac{x_{i}}{100} \times(Y-a)$.

Figure 2 gives general demonstration of the contributions scheme for international union of three member-states. 


\section{Figure 2. Budgetary contributions}

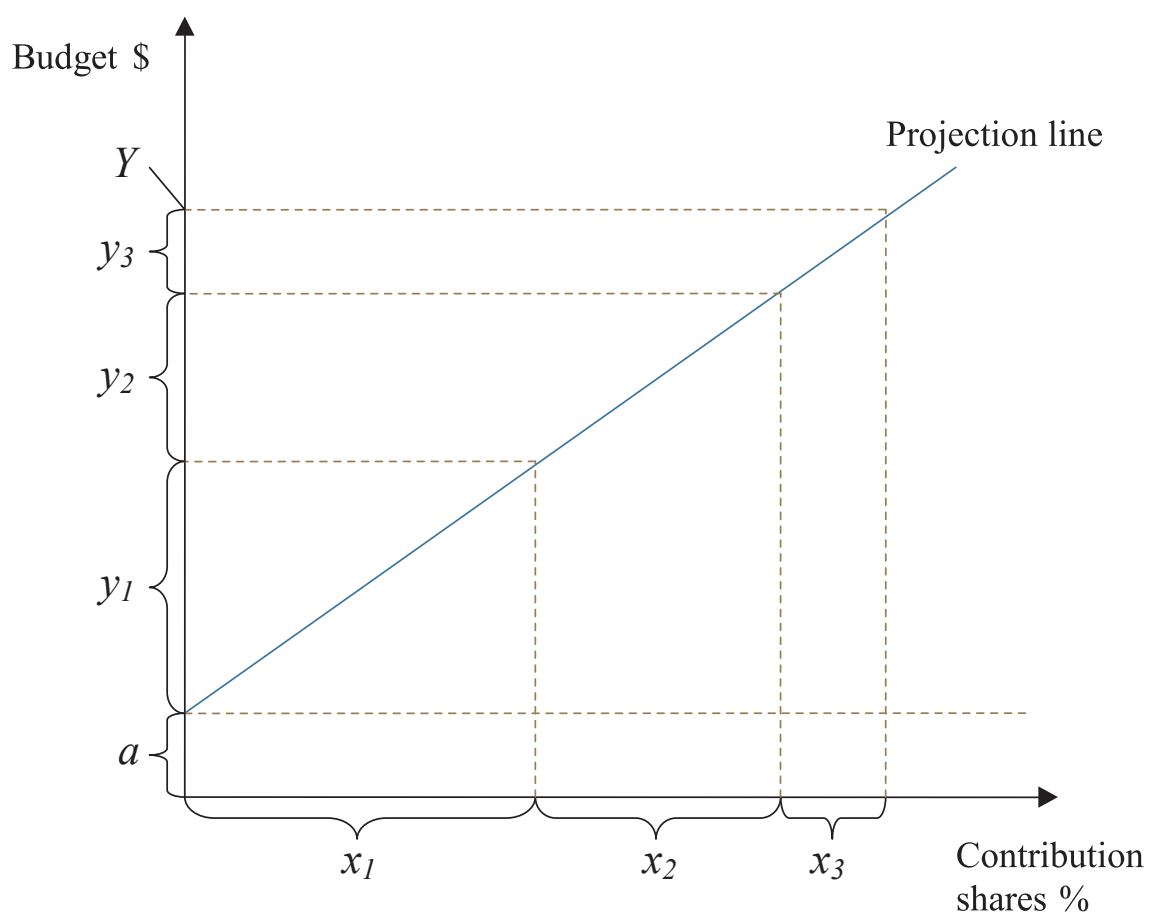

Denoted under $a$, non-contribution revenues can include fines for violation of the union legislation, surpluses available from the preceding financial years, income received from services provided by the administrative bodies, taxes paid by the union employees, donations from the third parties of individuals, legal entities, states or international organizations, borrowings etc.

There is no common rule on how to determine percentage shares of separate member-states in total budgetary contributions $x_{i}$. Different principles can underlie them. In general, three main approaches can be singled out with respect to this issue: (i) contributions are manually agreed by politicians without clear underlying rule (political trade-off) ${ }^{38}$; (ii) contributions are linked to some institutional parameter (usually the number of votes each country has in main decision-making bodies of the union) ${ }^{39}$; (iii)

\footnotetext{
${ }^{38}$ They are decided to be in equal shares in ASEAN, GCC, EAC, SICA and MERCOSUR fixed at agreed levels and reconsidered regularly in CEFTA and UNASUR, etc.

${ }^{39}$ As it is in EurAsEC and as it was in CUBKR.
} 
contributions are linked to some macroeconomic indicators like $\mathrm{GDP}^{40}, \mathrm{GNI}^{41}$ or a base for some tax ${ }^{42}$ during a particular period of time.

Under the first two approaches, contributions are legally fixed as stable percentage shares in the union's budget. These shares usually stay unchanged for many years ${ }^{44}$ and their absolute monetary sizes depend only on the amount of total expenditures decided.

Under the third approach, member-states' percentage shares in the union's budget change every financial year following changes in total expenditures and in basic macroeconomic variables. In this case, legislator determines and approves a percentage share, $X$ that each member-state pays as its contribution to the common budget as,

$$
X=\frac{Y-a}{\sum_{i=1}^{n} M_{A C R O}}
$$

where $Y$ represents budget size in the planned financial year; $a$ represents other (noncontribution) budgetary revenues; $n$ represents number of member-states in a union; $M A C R O_{i}$ represents value of basic macroeconomic parameter of state $i$ in basic period.

Upper or lower limits on revenues ${ }^{45}$ or on their growth rates ${ }^{46}$ can be established in revenue-generating schemes of such kind. Member-states carry their contributions as direct transfers from national budget according to the union legislative act. In some cases, it can be reasonable to link budgetary contributions to such macroeconomic variables as intra-union turnover or export in primarily trade liberalization blocks, national gold, and foreign currency reserve for unions whose main goal is macroeconomic stabilization in the region, or for the unions that carry common commercial policy.

One of the main advantages of the contributions scheme is that it is relatively simple and easy to understand for wide population of the public. Additionally, contributions scheme significantly reduces the risks of unbalanced budget since macroeconomic

\footnotetext{
${ }^{40}$ As in EFTA, CARICOM, SADC and some others.

${ }^{41} \mathrm{As}$ in EU.

${ }^{42}$ Part of national budgetary contributions in EU is linked to Value Added Tax (VAT) base.

${ }^{43}$ It can be forecasted values of the basic parameter for the planned financial year (as in EU), actual three-year averages for preceding financial years (EFTA), etc.

${ }^{44}$ Unless some significant institutional arrangements are undertaken in the union (enlargement, institutional or legislative reforms etc.).

${ }^{45}$ It is the EU case, where maximum amount of own resources generated is limited at $1.23 \%$ of the EU GNI.

${ }^{46} \mathrm{As}$ in SADC and EU.
} 
situation is considered as the second order factor. Budget deficit or surplus can occur in the case when parameter $a$ (non-contribution revenues) is miscalculated or when some members fail to carry out their financial obligations. To avoid such problems, union legislation should allow technical budgetary corrections and impose sanctions for states that violate their budgetary responsibilities.

On the other hand, contributions scheme creates direct financial dependence of the union upon political will of its member-states. It is the main shortcoming of this scheme.

\section{B. Direct taxes}

Under direct taxes scheme, it does not necessarily mean the creation of special supranational tax administration. Tax authorities of member-states are responsible for collecting and transferring such resources. Budgetary planning in this case is revenuebased, that is expenditures are directly limited by the amount of expected tax revenues.

In the case when only one supranational tax is introduced or other taxes are steady in time, captured with $a$ parameter, budgetary function can be described by the linear equation:

$$
Y=a+b \times X
$$

where $Y$ is planned level of revenues; $a$ represents other budgetary revenues; $b$ represents tax rate; $X$ represents expected size of the tax base in a particular financial year in all member-states. Graphically this dependence is demonstrated in Figure 3. 
Figure 3. Direct supranational tax

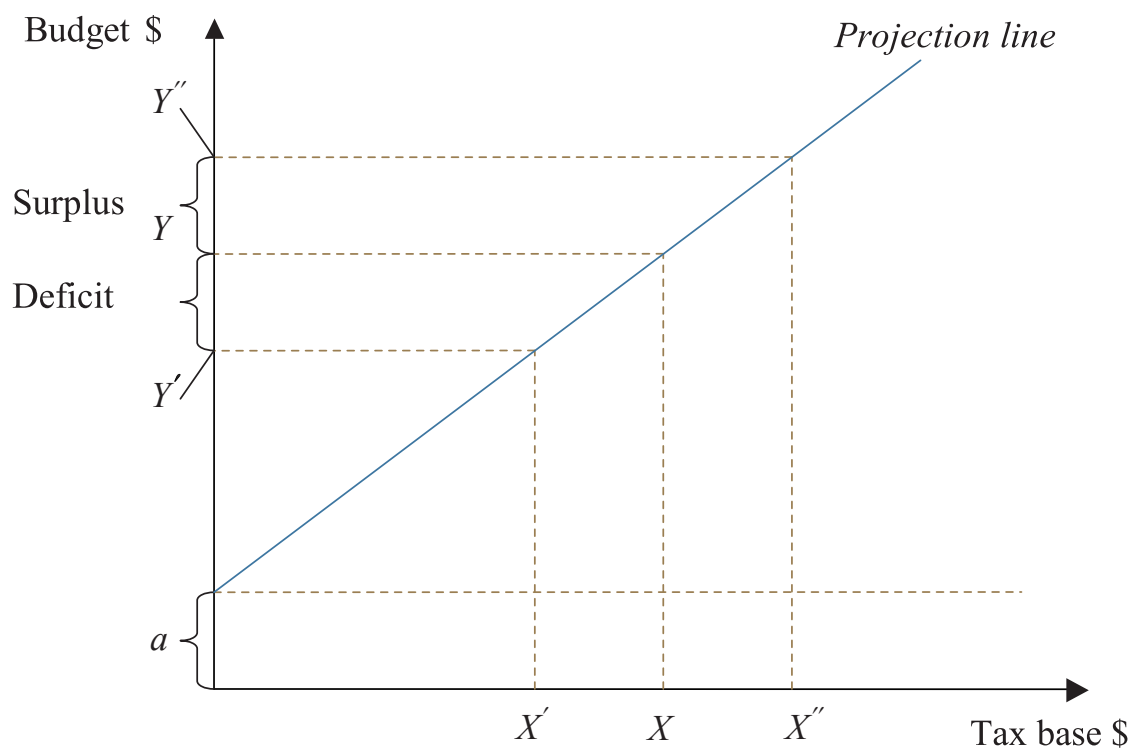

Budgetary balance is directly affected by the macroeconomic volatility in memberstates. In Figure 3, values $X^{\prime}$ and $X^{\prime \prime}$ reflect real sizes of the tax base in some financial years while $X$ is its expected size that cause deficit $\left(Y-Y^{\prime}\right)$ and surplus $\left(Y^{\prime \prime}-Y\right)$, correspondingly.

For simplicity, in this model it is assumed that tax base is aggregate, meaning it embraces corresponding tax bases of all the union member-states. In practice, however, there is a need to separate tax bases in every member-state since tax collection is carried out by separate national authorities and there should be a mechanism to control execution of budgetary responsibilities by member-states.

If an international union's budget is financed by a few supranational taxes, Equation (3) will be rewritten as follows:

$$
Y=a+\sum_{j=1}^{k}\left(b_{j} \times X_{j}\right)
$$

where $k$ represents a number of supranational taxes; $b_{j}$ represents tax rate for $\operatorname{tax} j ; X_{j}$ represents an expected size of aggregate tax base for tax $j$. 
Splitting the tax base by member-states (under single tax rate in all the states) will transform the Equation (4) into,

$$
Y=a+\sum_{j=1}^{k}\left(b_{j} \times \sum_{i=1}^{n} X_{j i}\right)
$$

where $n$ represents a number of international union member-states and $X_{j i}$ represents an expected tax base for tax $j$ in member-state $i$.

Each national tax administration is obliged to forward tax revenue assigned to the union's budget until depletion of its national quota. To establish these quotas, the same approaches can be used as in case of calculation of contributions presented in the subsection III-A.

An advantage of the direct taxes scheme is its ability to provide more automatic financing of the union's budget and to decrease financial dependence of the union from internal political factors. ${ }^{47}$ Establishment of supranational taxes as a source of revenue of an international union's budget can also increase political and financial responsibility of the union officials and institutions to the public. Therefore, it makes more sense to impose the implementation of policies on the union bodies. For example, (1) customs policy - import duties (2) tax harmonization - indirect taxes (3) free movement of capital - taxes from financial transactions (4) competition policy - fines paid for infringement of the union competition law.

From the theory of fiscal federalism's point of view, transfer to supranational bodies whose tax bases are significantly spatially diverse, will increase efficiency of tax and fiscal policies (Fiscal federalism 1997). Import duties, excise-duties, value added tax, financial transactions tax are some examples of such taxes. ${ }^{48}$

Higher risk of budget deficit and relative complexity are the main shortcomings of the direct tax scheme compared to contributions model.

Creation of a tax union should be considered as the culmination of the direct taxes scheme. It will lead to the establishment of supranational tax authorities and full or significant loss of sovereignty of the union member-states as for tax policy. If this is

\footnotetext{
${ }^{47}$ In some international unions (EU, WAEMU, CEMAC) principle of automatic (independent) financing is reflected in the concept of own resources.

${ }^{48}$ As it was mentioned in Section II import duties are a source of revenue for EU, SACU, CEMAC, WAEMU, ECOWAS and COMESA; excise-duties - for SACU and WAEMU. Financial transactions tax and traditional VAT (part of it) are planned to be established in EU until the end of current decade.
} 
the case, financing of an international union's budget would have large similarity to budgeting in federal states. So far, there were no precedents of tax unions in the modern history of economic integration.

\section{Mixed scheme}

In mixed financing scheme, advantages of both contributions and direct taxes schemes can be combined. For example, some supranational taxes can be introduced to provide an international union with own financial resources. Together with other non-tax and non-contributing revenues, they will ensure significant part of the union's budgetary revenues. The rest of financial resources needed to cover expenditures should be obtained through contributions scheme. This will make contributions a residual resource and minimize the risks of budget deficit to occur.

Combining contributions and taxes makes revenue-generating scheme complicated and opaque which is the main disadvantage of the mixed scheme.

\section{Selection of Revenue-Generating Scheme}

Intentionally, optimal revenue-generating scheme for international unions is not specified in this study. This would be inappropriate since the scheme has to be adapted according to each union's unique legal, political, institutional, economic and sociocultural setting. Thus, determinants that underlie the choice of the revenuegenerating scheme is the last important issue to be discussed here.

There are several groups of such determinants. First of all, it is financial needs of an international union or, to be more specific, its budget size. If the needs are relatively small, the question to which revenue-generating scheme to choose is of little principle. Member-states can easily agree to finance common budget with equal shares by simple contributions from national budgets. If, however, the union is expected to dispose large

\footnotetext{
${ }^{49}$ In EU these contributions are calculated proportionally to member-states' shares in the EU GNI (GNI resource - Section II). Equation (2) is used for this purpose. Some prototype of a mixed scheme is also proper to COMESA. There are intentions to establish mixed scheme of revenue-generating in CARICOM (CARICOM 2006).
} 
financial resources, more diverse revenue sources could be more preferable. A question of fair formula as for distribution of budgetary liabilities among member-states can sharply arise.

Secondly, the form of integration and its objectives matter. Higher level of integration (economic and/or monetary union, common market) can afford more diverse financing schemes (contributions linked to various macroeconomic parameters, variety of supranational taxes, fines etc.) since the authorities have more powers. At the same time, customs unions can only rely on import duties and contributions. For FTA, contributions seem to be the only option.

Political, economic, sociocultural, historical, geographical peculiarities of the parties make the third group of determinants. General rule here is as follows: with more heterogenous member states, financing schemes should allow more differentiated budgetary payments by its member-states. If international union is created closely with all these terms, nations can gain larger and more diverse revenues. On the contrary simple, transparent, and fair revenue-generating rules can be adapted by member-states and their public.

Success of integration project is also an important factor. If citizens of memberstates feel improvements in their work and life conditions that are due to successful fulfillment of international union's projects, the enhancement of the union revenuegenerating system can be undertaken.

Based on these observations, it can be expected that financing schemes will become more and more complicated as international unions advance and need larger financial resources. Simple contributions schemes will be supplemented with supranational taxation elements transforming, thus, into mixed schemes. Additional evidence that the mixed schemes will become more popular in the future is found in the fact that in this revenue-generating model, advantages of extreme polar cases can be successfully combined. The EU experience confirms it as well.

In most cases, the type of revenue-generating scheme chosen by an international union plays minor role for political and financial stability of the union. What is more important is if the whole budgetary system (revenues and expenditures together) is perceived by the parties as fair. The best way to ensure the fairness is to make members' budgetary payments proportionate to the utility that the states receive from integration. 


\section{References}

Alesina, Alberto, Ignazio Angeloni and Federico Etro. (2005), "International Unions", The American Economic Review, 95(3): 602-15.

ASEAN (Association of Southeast Asian Nations) (2007), The Association of Southeast Asian Nations Charter, Singapore.

Balassa, Bela. (1961), “The Theory of Economic Integration”, Homewood, Illinois: Richard D. Irwin.

Бояр (Boiar) А. О. (2013), “Оптимізація обсягів платежів держав-членів до бюджету інтеграційного угруповання”, Вчені записки КНЕУ, 15: 158-165.

Buti, Marco and Mario Nava. (2003), “Towards a European Budgetary System”, RSC No 2003/8, Florence: Robert Schuman Centre for Advance Studies.

CAN (Andean Community) (1969), "Official Codified Text of the Andean Subregional Integration Agreement", Cartagena.

CARICOM (Caribbean Community) (2006), "Report of the Technical Working Group on Governance Approved by CARICOM Heads of Government Managing Mature Regionalism: Regional Governance in the Caribbean Community", Port of Spain: University of the West Indies.

Carruba, C. J. (1997), "Net Financial Transfers in the European Union: Who Gets What and Why?", Journal of Politics, 59: 469-96.

CEFTA (Central European Free Trade Agreement) (2007), "Decision of the Joint Committee of the Central European Free Trade Agreement", No. 7/2007: Mandate of the Secretariat, Ohrid.

CEMAC (Economic and Monetary Community of Central Africa) (2000), “Acte Additionnel No 03/00-CEMAC 046-CM-05", Instituant un mécanisme autonome de financement de la Communauté, Bangui.

CEMAC (2008), Traité Révisé de Communauté Économique et Monétaire de l'Afrique Centrale, Yaoundé.

CEMAC (2011), "Reglement No 03/11-CEMAC-132-CM-22", arrêtant et rendant exécutoire les Budgets des Institutions et Organismes spécialisés de la Communauté- 
Exercice 2012, Bangui.

CEMAC (2011), "Reglement N ${ }^{\circ}$ 02/11-CEMAC-132-CM-22", arrêtant et rendant exécutoire le Budget du Fonds de Développement de la Communauté (FODEC) Exercice 2012, Bangui.

COMESA (Common Market for Eastern and Southern Africa) (1993), “Agreement Establishing the Common Market for Eastern and Southern Africa”, Kampala.

CUBKR (Таможенный союз Беларуси, Казахстана и России) (2007), Договор о Комиссии таможенного союза, Душанбе.

EAC (East African Community) (1999), "East African Community Treaty”, Arusha.

ECOWAS (Economic Community of West African States) (1993), "Revised Treaty of the Economic Community of West African States", Cotonou.

EFTA (European Free Trade Area) (2009), "EFTA Financial Regulations", Ref. 1067029v4. Geneva.

EFTA (2012), “EFTA Secretariat-Financial reports 2011”, Ref. 32331. Geneva.

EFTA (2013), “EFTA Budget”, accessed October 16, 2013, http://www.efta.int/aboutefta/efta-budget.aspx

EU (2007), "Council Decision 2007/436/EC, Euratom of 7 June 2007 on the system of the European Communities' own resources", Brussels.

EU (European Union) (2008), “Consolidated version of the Treaty on the Functioning of the European Union", Lisbon.

GCC (Gulf Cooperation Council) (1981), "The Charter of the Cooperation Council for the Arab States of the Gulf', Abu Dhabi.

Hix, Simon. (1999), "The Political System of the European Union”, McMillan, Basingstoke.

Hoole, Brian L. Job and Harvey J. Tucker. (1976), "Incremental Budgeting and International Organizations", American Journal of Political Science, 20: 273-301.

International Monetary Fund (1997), "Fiscal federalism in theory and practice", Edited by Ter-Minassian T, IMF, Washington. 
International Labour Office (2013), "Financial arrangements in SAARC", accessed October 16, 2013, http://actrav.itcilo.org/actrav-english/telearn/global/ilo/blokit/saarc. htm\#FINANCIAL ARRANGEMENTS IN SAARC

Kirk, Robert and Matthew Stern. (2003), "The New Southern African Customs Union Agreement”, Africa Region Working Paper Series, June 2003, No 57.

Meade, James E. (1955), "The Theory of Customs Unions", The North Holland Publishing Co., Amsterdam

MERCOSUR (Southern Common Market) (1994), "Additional Protocol to the Treaty of Asunción on the Institutional Structure of MERCOSUR”, Ouro Preto.

MERCOSUR (2010), MERCOSUR/CMC/DEC. No 50/10 Fondo para la Convergencia Estructural del MERCOSUR Presupuesto 2011.

MERCOSUR (2012), MERCOSUR/GMC/RES. No 47/12 Presupuesto de la Secretaria del MERCOSUR para el Ejercicio 2013.

NAFTA (North American Free Trade Agreement) (2013), “About NAFTA Secretariat: Overview", accessed October 16, 2013, https:/www.nafta-sec-alena.org/Default. aspx?tabid $=88 \&$ language $=$ en-US

OECS (Organisation of Eastern Caribbean States) (2008), "Economic Union Treaty: Frequently Asked Question", Castries.

OECS (2010), "Treaty of Basseterre Establishing the Organisation of Eastern Caribbean States Economic Union", Gros Islet.

OECS (2012), "Summary of OECS Annual Work Programme: July 2012 - June 2013”, OECS Secretariat, Castries.

Pietras, Jaroslaw. (2008), "The Future of the EU Budget: in Search of Coherence of Objectives, Policies and Finances of the Union", DemosEUROPA-Centre for European Strategy, Warsaw

SAARC (South Asian Association for Regional Cooperation) (2008), "Charter of the SAARC Development Fund (SDF)", Colombo.

SACU (Southern African Customs Union) (2002), "Southern African Customs Union Agreement", Gaborone. 
SACU (2013), "SACU Annual Report 2012: Implementing a common agenda towards Regional Integration", SACU Secretariat, Windhoek

SADC (Southern African Development Community) (1992), "Treaty of the Southern African Development Community", Windhoek.

SADC (2009), "Activity Report of the Secretariat for the Period August 2007 to July 2008", SADC Secretariat, Gaborone.

SICA (Sistema de la Integración Centroamericana) (1962), “Carta de la Organizacion Estados Centroamericanos (ODECA)", Panama.

SICA (1991), "Tegucigalpa Protocol of the Charter of the Organization of the Central American States", Tegucigalpa.

Simon, Jenny and Justin M. Valasek. (2012), "Efficient Fiscal Spending by Supranational Unions", WZB (Wissenschaftszentrum Berlin für Sozialforschung) Discussion Paper SP II 2012-305.

Tabellini, Guido. (2003), "Principles of Policy making in the European Union: an Economic Perspective", CES Ifo Economic Studies, 49 (1): 49-75.

Tinbergen, Jan., (1965), “International Economic Integration”, 2nd eds. Amsterdam: Elsevier.

Viner, Jacob., (1950), “The Customs Union Issue”, Carnegie Endowment International for Peace.

UNASUR (Union of South American Nations) (2008), "The South American Union of Nations Constitutive Treaty", Brasilia.

WAEMU (West African Economic and Monetary Union) (1994), “Traite de L'union Economique et Monetaire Ouest-Africaine (UEMOA)", Dakar.

Бояр (Boiar) А. О. (2013), “Оптимізація обсягів платежів держав-членів до бюджету інтеграційного угруповання”, Вчені записки КНЕУ, 15: 158-165. 